\title{
Extravalvular exoprosthetic repair of aortic root: first experience
}

\author{
Pozazastawkowa egzoprotetyczna naprawa korzenia aorty: \\ pierwsze doświadczenie
}

\author{
Alexander Chernyavskiy, Sergey Alsov, Dmitry Khvan, Dmitry Sirota \\ Ye.N. Meshalkin Research Institute of Circulation Pathology, Novosibirsk, Russian Federation
}

Kardiochirurgia i Torakochirurgia Polska 2012; 9 (4): 409-414

\begin{abstract}
Background: Understanding the processes underlying insufficiency progression in patients with ascending aortic pathologies, as well as the structure and aortic root function, has become the basis for the development and implementation of extravalvular exoprosthetic repair of the aortic root (the Florida sleeve procedure).

Material and methods: The study encompassed 10 patients with ascending aortic aneurysm with concomitant aortic insufficiency (Al) (from moderate to severe) who underwent extravalvular exoprosthetic repair of the aortic root (the Florida sleeve technique) and had a 30-day early postoperative follow-up. The mean age was $52.2 \pm 18.28$ years. The following concomitant diseases were revealed: aortic dissection in 3 patients (DeBakey type I in 2, DeBakey type II in 1), and Marfan syndrome in 2 patients. Data were acquired preoperatively and postoperatively.

Results: Postoperative echocardiographic studies demonstrate that the degree of Al decreased from the average value of 2.4 \pm 0.7 preoperatively down to $0.9 \pm 0.74(p=0.01)$ postoperatively. Mention should also be made of reverse remodeling of the left ventricle: a decrease was noted in end-diastolic volume (EDV) from $157.06 \pm 43.97 \mathrm{ml}$ before the operation down to $127.88 \pm 48.91 \mathrm{ml}(p=0.2)$ after the operation. No reoperation for Al was required during the 30-day follow-up. 30-day mortality was observed in one case.

Conclusions: Extravalvular exoprosthetic repair of the aortic root shows satisfactory early results. Yet, in order to analyze its early and long-term outcomes, there should be more patients involved. This could determine the advisability of the given technique when selecting surgical treatment of ascending aortic aneurysms with concomitant aortic insufficiency.
\end{abstract}

Key words: aortic aneurysm, aortic insufficiency, aortic repair.

\section{Streszczenie}

Wstęp: Zrozumienie procesów leżących u podstaw progresji niewydolności u pacjentów z patologiami aorty wstępującej oraz budowy i funkcji korzenia aorty położyło fundament pod wynalezienie i implementację pozazastawkowej egzoprotetycznej naprawy korzenia aorty (technika Florida sleeve).

Materiał i metody: Badaniem objęto 10 pacjentów z tętniakiem aorty wstępującej z towarzyszącą niewydolnością aorty (aortic insufficiency - Al) w stopniu od umiarkowanego do ciężkiego. U pacjentów wykonano pozazastawkową egzoprotetyczną naprawę korzenia aorty (techniką Florida sleeve), a następnie poddano ich 30-dniowej obserwacji pooperacyjnej. Średnia ich wieku wyniosła 52,2 $\pm 18,28$ roku. Ujawniono następujące choroby towarzyszące: rozwarstwienie aorty u 3 pacjentów (u 2 - typ I DeBakeya, u 1 - typ II DeBakeya), oraz zespół Marfana u 2 pacjentów. Dane gromadzono zarówno przed zabiegiem, jak i pooperacyjnie.

Wyniki: Badania EKG wykonywane podczas obserwacji pooperacyjnej wskazują na zmniejszenie niewydolności aorty ze średniej wartości 2,4 $\pm 0,7$ przed operacją do 0,9 $\pm 0,74$ ( $p=0,01)$ po operacji. Należy wspomnieć również o wstecznej przebudowie (reverse remodeling) lewej komory: objętość końcoworozkurczowa (end-diastolic volume - EDV) zmniejszyła się z 157,06 $\pm 43,97 \mathrm{ml}$ przed operacją do 127,88 $\pm 48,91 \mathrm{ml}$ $(p=0,2)$ po operacji. W ciągu 30 dni obserwacji pooperacyjnej nie była potrzebna żadna powtórna operacja niewydolności aorty. W ciągu 30 dni nastąpit jeden zgon pacjenta.

Wnioski: Wczesne wyniki pozazastawkowej egzoprotetycznej naprawy korzenia aorty są zadowalające. Bez wątpienia do zbadania krótko- i długoterminowych rezultatów potrzebne byłoby uczestnictwo większej liczby pacjentów. Umożliwiłoby to ustalenie okoliczności, które dyktowałyby wybór tej metody podczas dobierania techniki operacyjnej dla pacjentów z tętniakiem aorty wstępującej z towarzyszącą niewydolnością aorty.

Słowa kluczowe: tętniak aorty, niewydolność aorty, naprawa aorty. 


\section{Introduction}

Modern surgeons treating ascending aortic aneurysms with concomitant aortic insufficiency (Al) have at their disposal a whole set of standard valve-sparing procedures that work well in practice. These include supracoronary replacement of the ascending part of the aorta, as well as aortic root reimplantation and remodeling, introduced by Frater, David and Feindel, and Sarsam and Yacoub, respectively [1-3].

Twenty years have passed since David first published the results of his study on the reimplantation of the aortic valve into a synthetic prosthesis in patients with ascending aortic aneurysm and concomitant aortic insufficiency. Over this period, the technique has not only turned into something of a "gold standard" in valve-sparing aortic root surgery, but it also made a great impact on the development of this trend and the general attitude towards this kind of intervention. Although this technique has been used for a long time, preserving the native aortic valve remains the exclusive prerogative of large centers that have extensive experience in this type of operative intervention. Great complexity, considerable duration and certain unpredictability are the main challenges for the wide use of valvesparing operations, while the choice of graft and the visual assessment of repair quality largely depend on the cardiac surgeon's experience [4-6]. In 1968, Bentall and DeBono described the technique of complete replacement of the aortic root with a mechanical valve. This procedure offers reliable outcomes, good reproducibility and relative simplicity of performance, as well as decent long-term survival and mortality [7-9]. It is not surprising that complete aortic root replacement with a composite valve graft has become a widely used method for treating the aforementioned pathology. Nonetheless, in spite of the obvious advantages that this method could offer, there are some drawbacks related to the use of the mechanical valve, namely, the need for lifelong anticoagulant therapy and the risk of bleeding that might accompany the latter, prosthetic endocarditis, valve dysfunction, and thromboembolism. Therefore, a growing number of surgeons tend to select valve-sparing surgery as their operation of choice [8, 10-12]. The survival and fre-

Tab. I. Patients' preoperative data

\begin{tabular}{lc} 
Parameter & Value \\
age & $52.2 \pm 18.28(23-71)$ \\
\hline gender (male) & $60 \%(6)$ \\
\hline body surface area & $1.85 \pm 0.17(1.52-2.04)$ \\
\hline ejection fraction (EF) & $62.9 \pm 8.32(52-76)$ \\
\hline Marfan syndrome & $20 \%(2)$ \\
\hline aortic dissection & $30 \%(3)$ \\
\hline chronic heart failure (NYHA) & $2.5 \pm 0.71(1-3)$ \\
\hline arterial hypertension (AHT) & $60 \%(6)$ \\
\hline aortic regurgitation (+) & $2.4 \pm 0.7(1-3)$ \\
\hline annulus diameter & $27.1 \pm 2.33(25-32)$ \\
\hline
\end{tabular}

edom from reoperation following valve-sparing operations in patients with ascending aortic aneurysm and concomitant Al compare favorably to the outcomes of Bentall and DeBono operations [12-14]. The outcomes of valve-sparing techniques match those obtained with complete replacement of the aortic valve with a composite valve graft. This makes it possible to secure good quality of life in patients and contributes to cardiac surgeons' decisions to preserve the native valve [11, 12].

The development of surgery for the aortic valve has shifted from its complete replacement to preserving the complete aortic root system. Understanding the processes underlying insufficiency progression in patients with ascending aortic pathologies, as well as the structure and aortic root function, has become the basis for the development and implementation of extravalvular exoprosthetic repair of the aortic root (the Florida sleeve procedure), a new approach to valve-sparing surgery for the aortic root [15]. The technique offered by Philip J. Hess and co-authors entails reimplantation of the entire aortic root into a Dacron graft. The graft must be of a proper size required to obtain adequate aortic valve competence and to avoid re-implanting the coronary artery ostia. Combining all the advantages of full aortic root replacement with a composite valve graft with those of valve-sparing procedures (i.e. simplicity, speed, reproducibility, low risk of complications, preservation of the native valve and the entire aortic root system), extravaIvular exoprosthetic repair of the aortic root is a good alternative to existing conventional techniques $[15,16]$.

\section{Material and methods}

Since July 2011, 10 operations have been performed using the Florida sleeve technique in patients with ascending aortic aneurysm and concomitant Al, from moderate to severe. The following concomitant defects were revealed: aortic dissection in 3 patients (DeBakey type I in 2, DeBakey type II in 1), and Marfan syndrome in 2 patients. One patient also had arteria lusoria. The mean NYHA functional class of chronic heart failure was 2.5. Five patients had grade III hypertension. Table I presents detailed preoperative data of the patients. In order to preoperatively assess the size of the aortic root and the degree of $\mathrm{Al}$, all patients underwent echocardiography.

\section{Extravalvular exoprosthetic repair of aortic root}

Median sternotomy was used as the surgical approach. The cardiopulmonary bypass was connected according to the following scheme: ascending aorta - right atrium or right subclavian artery - right atrium, depending on the volume of operative intervention. When circulatory arrest was needed, use was made of antegrade cerebral perfusion under moderate hypothermia $\left(25^{\circ} \mathrm{C}\right)$. The left parts of the heart were drained through the right proximal pulmonary vein. Following extracorporeal circulation, the aorta was occluded. The ascending aorta was transected $2 \mathrm{~cm}$ above the sino- 
tubular junction, and then antegrade chemical/hypothermic cardioplegia was induced using Custodiol solution $(20 \mathrm{ml} / \mathrm{kg})$, which was selectively administered into the ostia of the coronary arteries.

Subsequently, the aortic root and aortic valve were inspected and visually assessed. Special emphasis was placed on the state of the cusps (evident fibrosis, calcification getting over the fibrous annulus, as well as pathological elongation of the cusp edges were considered to be contraindications for valve preservation), as well as on the relationships between the aortic root components (Fig. 1). The aortic root was fully detached circumferentially down to the level of aorto-ventricular contact. Great

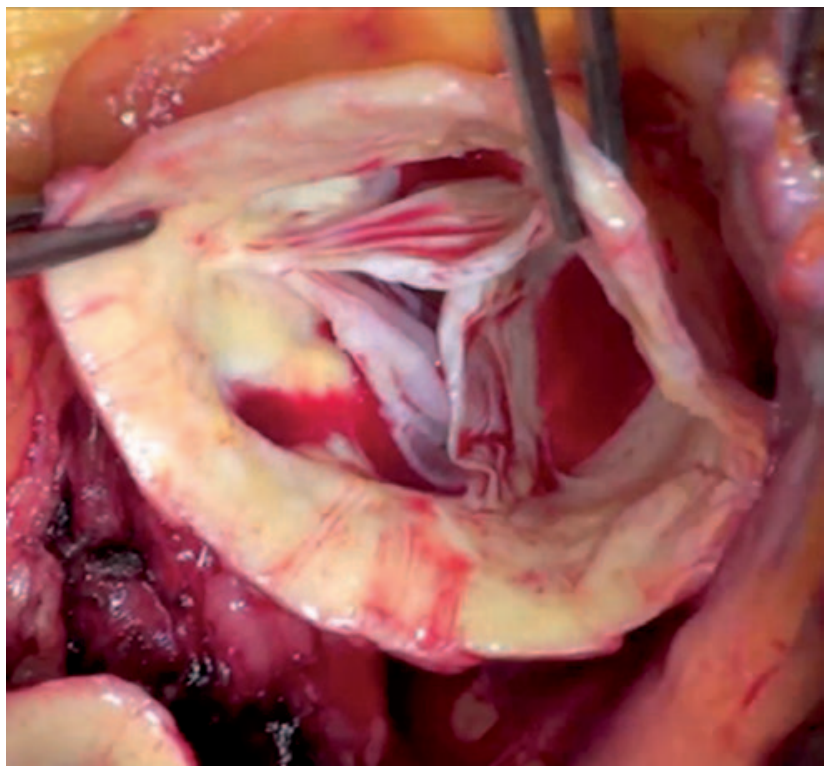

Fig. 1. Inspection of the aortic valve prior to valve-sparing surgery

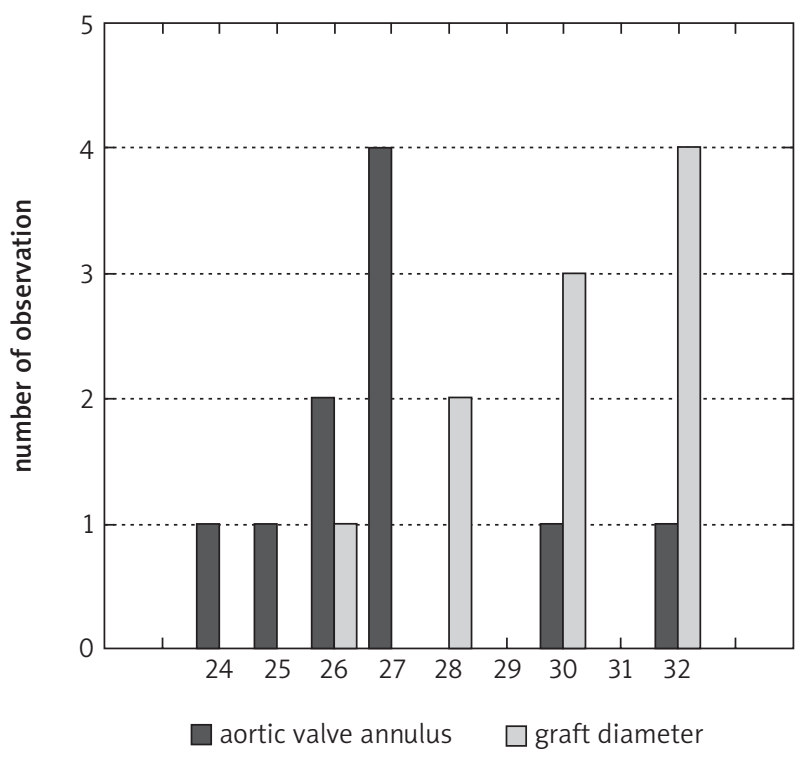

Fig. 2. Distribution of fibrous annulus diameters of aortic valve and graft sizes care was exercised while dissecting the proximal part of the coronary arteries and detaching the aortic root from under them. Calibrators of standard diameter were used for measurement of the aortic valve annulus. The target diameter of the annulus depended on this measurement and on the degree of dilatation of the sinuses of Valsalva. We also performed modeling of the aortic root components under visual control in order to provide good coaptation of the cusps and proper function of the aortic valve. At the same time the graft size had to be large enough to hold the dilated aortic root. When the dilatation of the non-coronary sinus and/or sinotubular junction was considerable, linear plication plasty of the sinus was performed, with or without suturing the sinotubular junction. Subannular mattress sutures were then placed horizontally and circumferentially a few millimeters below the aortic annulus and brought out through an outflow duct of the left ventricle. These sutures are typically used to fix the graft to the left ventricle outflow tract and are not considered to be haemostatic.

To implant the aortic root, special attention was given to the preparation of the graft. When performing extravaIvular exoprosthetic repair of the aortic root, grafts with artificial sinuses of Valsalva were used in all cases. The distribution of aortic valve annulus diameters and graft sizes is shown in Fig. 2.

The positions of the coronary arteries were first marked on the graft and then vertical grooves were cut to those marks (Fig. 3). The length of the grooves matched the distance from the aorto-ventricular junction, where the sutures come out, to a lower part of the coronary artery. At the location where the ostia of coronary arteries were to be located, round holes were made in the prosthesis with diameter $5 \mathrm{~mm}$ larger than that of the ostia of coronary arteries.

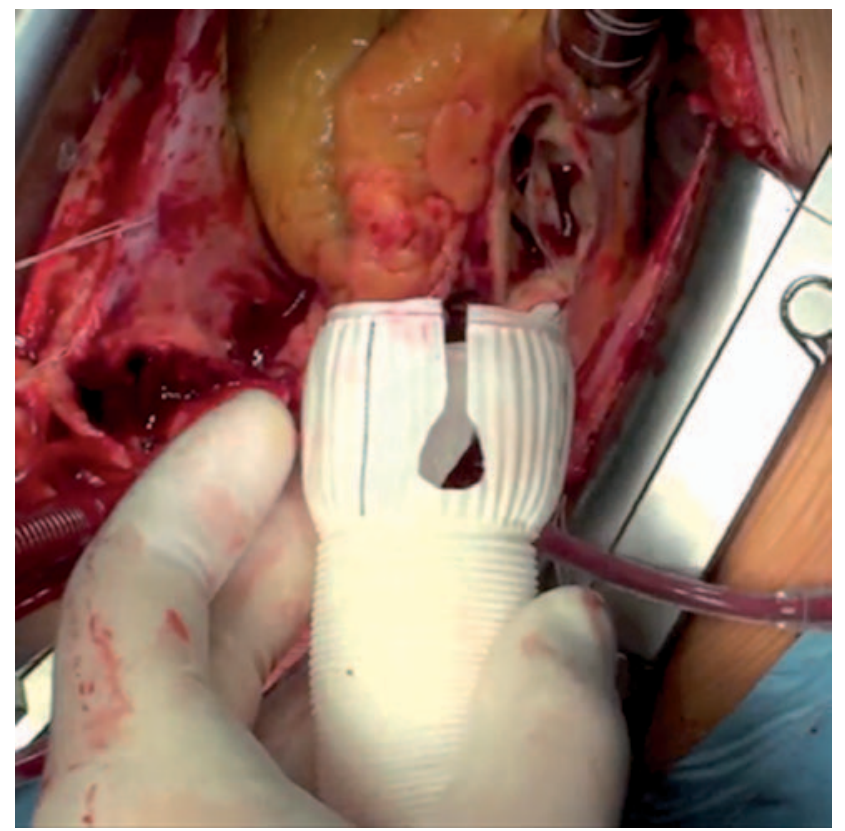

Fig. 3. Preparing the graft for root implantation 
The prepared graft was fixed to the outflow part of the left ventricle above the aortic root by means of subannular sutures running through the base of the graft. The cusps were then checked for coaptation, and the graft was cut at the level of the sinotubular junction.

The top of the graft and the sinotubular junction were sewn together by using a continuous monofilament suture. This marked the end of the stage of extravalvular exoprosthetic repair of the aortic root (Fig. 4). Finally, inter-graft anastomosis between the sinotubular junction and the ascending aortic graft or the ascending aorta was performed. The surgery was completed by using a standard protocol.

To check for $\mathrm{Al}$ and ensure the proper functioning of the aortic valve, every patient underwent intraoperative transoesophageal echocardiography.

\section{Results}

After the extravalvular exoprosthetic repair of the aortic root, three patients required additional plication of the noncoronary sinus with sutures due to excessive dilatation of the non-coronary sinus. In two cases the intervention was combined with aortic arch repair using the hemiarch technique: one patient had aortic arch aneurysm, the other DeBakey type 1 dissection. In one case extravalvular exoprosthetic repair was combined with intraoperative implantation of a Djumbodis stent into the aortic arch because of DeBakey type 1 dissection, while in another case it was combined with thoracoplasty due to the funnel chest of the Marfan syndrome patient. In one case, extravalvular exoprosthetic repair was combined with coronary artery bypass grafting. The operative intervention data are presented in Table II.

Postoperative follow-up echocardiographic studies demonstrate that the degree of Al decreased from the average preoperative value of $2.4 \pm 0.7$ (in the group) down to $0.9 \pm 0.74(p=0.01)$ postoperatively. Mention should also be made of the reverse remodeling of the left ventricle: a decrease was noted in end-diastolic volume (EDV) from 157.06 $\pm 43.97 \mathrm{ml}$ before the operation down to $127.88 \pm 48.91 \mathrm{ml}$ ( $p=0.2)$ postoperatively.

Postoperative complications during the 30-day follow-up are summarized in Table III. In the early postoperative period 1 patient had a non-Q-wave myocardial infarction and required inotropic support (for over 48 hours) and extended mechanical ventilation (which exceeded 48 hours).

No reoperation for $\mathrm{Al}$ was required during the 30-day follow-up.

30-day mortality was observed in one case and was related to an acute cerebrovascular accident resulting in extended artificial pulmonary ventilation.

\section{Discussion}

A considerable number of recently reported studies focus on the biomechanics of the aortic root and the aortic valve. Some researchers have indicated that the aortic root structure provides a significant reduction in stress on the aortic valve [17-19]. A characteristic feature of its structure is that the fibrous annulus, the commissures,

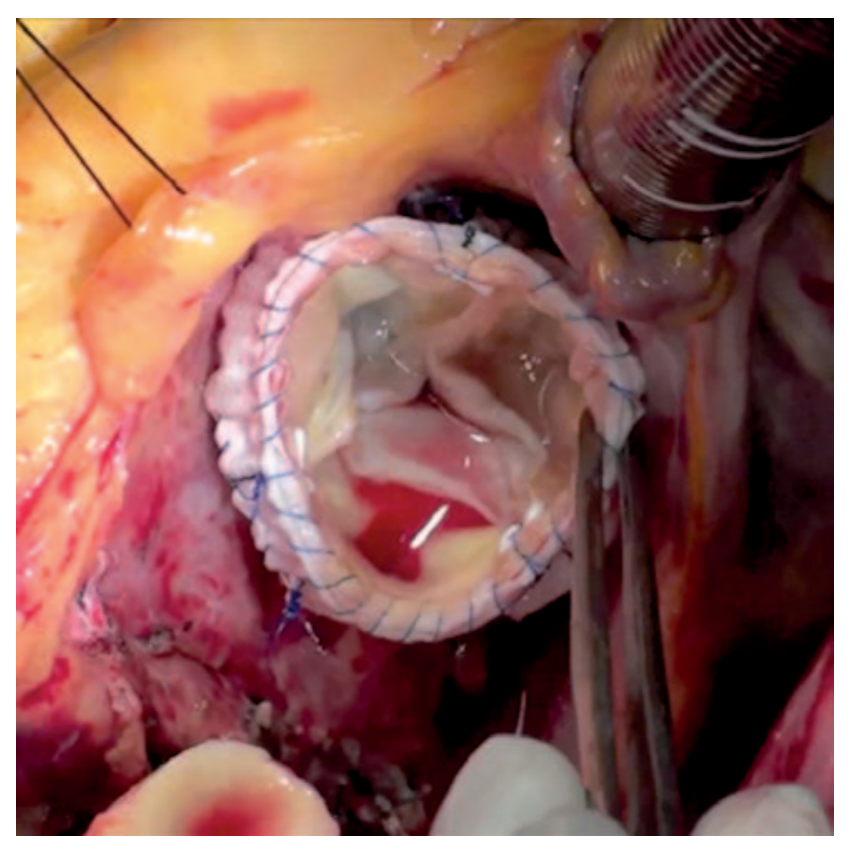

Fig. 4. Final view of completed extravalvular exoprosthetic repair of aortic root

Tab. II. Operative intervention data

\begin{tabular}{ll} 
Intervention name & N \\
Individual extravalvular exoprosthetic repair of aortic root & 4 \\
\hline + plasty of non-coronary sinus & 3 \\
\hline + aortic arch prosthetics (hemiarch) & 2 \\
\hline + Djumbodis & 1 \\
\hline + CABG & 1 \\
\hline + thoracoplasty & 1 \\
\hline
\end{tabular}

$C A B G$ - coronary artery bypass graft

Tab. III. Post-operative complications during the 30-day follow-up

\begin{tabular}{ll} 
AV block & $N$ \\
\cline { 2 - 2 } \multicolumn{1}{c}{ need of pacing } & 0 \\
\hline bleeding & 0 \\
\hline infectious complications & 0 \\
\hline reoperation & 0 \\
\hline stroke & 0 \\
\hline non-Q-wave myocardial infarction & 1 \\
\hline 30-day death & 1 \\
\hline inotropic support (> 48 h) & 1 \\
\hline atrial fibrillation & 1 \\
\hline extended mechanical ventilation (over 48 hours) & 2 \\
\hline
\end{tabular}

and the arch ring act as a framework of the system, while the valve and the sinuses of Valsalva work as its membranous components.

In 1989, Dzemeshkevich and Konstantinov confirmed the heterogeneity of the aortic root complex and the ani- 
sotropy of its resilience and strength [19]. Thus, owing to the redistribution of energy, the displacement and reciprocal adaptation of the aortic root components are provided, and stress on the aortic valve is relieved [17-19]. The aortic root functions as a unit, while the aortic valve works as an active element. As a result, the aortic valve starts opening before the beginning of the ejection of blood from the left ventricle during the isovolumic contraction phase [20, 21]. During cardiac output the cusps do not contact the aortic wall due to turbulent blood flow in the sinuses of Valsalva and, therefore, they are constantly present in the bloodstream.

According to the Bernoulli law, the turbulent blood flow behind the cusps in the sinuses of Valsalva and the laminar flow in the center of the aorta trigger the closure of the aortic valve, while bringing the cusps together before a pressure differential develops between the aorta and the left ventricle [22, 23]. Some authors have demonstrated that preserving the sinuses of Valsalva not only prevents a systolic contact of the cusps with the aortic wall and reduces the stress they undergo, but also restores healthy biomechanical function of the repaired root [24-27]. Therefore, we believe that the preserved aortic root system will have a great impact on the long-term functioning of the aortic valve, which will in turn contribute to the longevity of the performed procedure.

There is no agreement among researchers regarding the efficacy of these two procedures: aortic valve reimplantation and aortic root remodeling. Still, a growing number of studies indicate that this area presents a serious challenge. Positive outcomes of these procedures leave little room for other techniques to be developed. In fact, competitive procedures will be viable only if they are well thought out. The extravalvular exoprosthetic repair of the aortic root seems to fulfill this criterion.

This technique allows aortic root reconstruction to be combined with aortic valve annuloplasty. In addition, the use of this procedure makes it possible to strengthen the aortic root and sinuses of Valsalva, to repair the sinotubular junction, and to preserve the stereometry of aortic root components $[15,28]$. It also eliminates the need for reimplantation of coronary arteries, cutting out the sinuses, and fixing the commissures, which in turn reduces the risks of bleeding and potential torsion of coronary arteries during reimplantation.

At present, there are few studies highlighting the techniques for external fastening of the aortic root when treating ascending aortic aneurysms with concomitant aortic insufficiency [28-30]. Moreover, the total number of patients included in these studies did not exceed 50 . Nonetheless, the potential advantages of this technique and its satisfactory outcomes in the early follow-up period from 20.7 to 32 months $[29,30]$ make us hope that this valvesparing technique will receive the interest it deserves.

The analysis of the available data enables us to conclude that the described technique is feasible and safe. So far, no mortality related to aortic valve dysfunction or damage of coronary arteries has been observed [28-30]. According to Hess, the analysis of the dynamics of aortic insufficiency reveals a decrease in mean aortic regurgitation from 2.61 to 1.67 in 3 years, as well as a decrease in the average enddiastolic dimension (EDD) of the left ventricle, a predictor of reverse remodeling, from $51.6 \mathrm{~mm}$ to 47.1 in 3 years [29]. Roland Hetzer reports that in a cohort of 10 patients operated on using a modified "Florida sleeve" procedure, aortic regurgitation in all patients did not exceed $1+$ at mean follow-up of 20.7 months [30].

\section{Conclusions}

Extravalvular exoprosthetic repair of the aortic root shows satisfactory early results. Yet, in order to analyze its early and long-term outcomes, there should be more patients involved. This could determine the advisability of the given technique when selecting surgical treatment of ascending aortic aneurysms with concomitant aortic insufficiency, as well as expanding the range of operative interventions for patients with this pathology.

\section{Literature}

1. Frater RW. Aortic valve insufficiency due to aortic dilatation: correction by sinus rim adjustment. Circulation 1986; 74: I136-I142.

2. David TE, Feindel CM. An aortic valve-sparing operation for patients with aortic incompetence and aneurysm of the ascending aorta. J Thorac Cardiovasc Surg 1992; 103: 617-621.

3. Sarsam LA, Yacoub M. Remodeling of the aortic valve annulus. I Thorac Cardiovasc Surg 1993; 105: 435-438.

4. David TE, Feindel CM, Webb GD, Colman JM, Armstrong S, Maganti M. Longterm results of aortic valve-sparing operations for aortic root aneurysm. J Thorac Cardiovasc Surg 2006; 132: 347-354.

5. Hiratzka LF, Bakris GL, Beckman JA, Bersin RM, Carr VF, Casey DE Jr, Eagle KA, Hermann LK, Isselbacher EM, Kazerooni EA, Kouchoukos NT, Lytle BW, Milewicz DM, Reich DL, Sen S, Shinn JA, Svensson LG, Williams DM; American College of Cardiology Foundation/American Heart Association Task Force on Practice Guidelines; American Association for Thoracic Surgery; American College of Radiology; American Stroke Association; Society of Cardiovascular Anesthesiologists; Society for Cardiovascular Angiography and Interventions; Society of Interventional Radiology; Society of Thoracic Surgeons; Society for Vascular Medicine. 2010 ACCF/AHA/AATS/ACR/ASA SCA/SCAI/SIR/STS/SVM guidelines for the diagnosis and management of patients with Thoracic Aortic Disease: a report of the American College of Cardiology Foundation/American Heart Association Task Force on Practice Guidelines, American Association for Thoracic Surgery, American College of Radiology, American Stroke Association, Society of Cardiovascular Anesthesiologists, Society for Cardiovascular Angiography and Interventions, Society of Interventional Radiology, Society of Thoracic Surgeons, and Society for Vascular Medicine. Circulation 2010; 121: e266-e369.

6. Miller DC. Valve-sparing aortic root replacement in patients with the Marfan syndrome. J Thorac Cardiovasc Surg 2003; 125: 773-778.

7. Tsunekawa T, Ogino H, Matsuda H, Minatoya K, Sasaki H, Kobayashi J, Yagi hara T, Kitamura S. Composite valve graft replacement of the aortic root: twenty-seven years of experience at one Japanese center. Ann Thorac Surg 2008; 86: 1510-1517

8. Pacini D, Ranocchi F, Angeli E, Settepani F, Pagliaro M, Martin-Suarez S, Di Bartolomeo R, Pierangeli A. Aortic root replacement with composite valve graft. Ann Thorac Surg 2003; 76: 90-98.

9. Bentall H, De Bono A. A technique for complete replacement of the ascending aorta. Thorax 1968; 23: 338-339.

10. Radu NC, Kirsch EW, Hillion ML, Lagneau F, Drouet L, Loisance D. Embolic and bleeding events after modified Bentall procedure in selected patients. Heart 2007; 93: 107-112.

11. Kallenbach K, Pethig K, Schwarz M, Milz A, Haverich A, Harringer W. Valve sparing aortic root reconstruction versus composite replacement - perioperative course and early complications. Eur J Cardiothorac Surg 2001; 20: 77-81. 
12. Patel ND, Weiss ES, Alejo DE, Nwakanma LU, Williams JA, Dietz HC, Spevak PJ, Gott VL, Vricella LA, Cameron DE. Aortic root operations for Marfan syndrome: a comparison of the Bentall and valve-sparing procedures. Ann Thorac Surg 2008; 85: 2003-2010.

13. Hagl C, Strauch JT, Spielvogel D, Galla JD, Lansman SL, Squitieri R, Bodian CA, Griepp RB. Is the Bentall procedure for ascending aorta or aortic valve replacement the best approach for long-term event-free survival? Ann Thorac Surg 2003; 76: 698-703.

14. David TE, Maganti M, Armstrong S. Aortic root aneurysm: principles of repair and long-term follow-up. J Thorac Cardiovasc Surg 2010; 140 (6 Suppl): S14-S19.

15. Hess PJ Jr, Klodell CT, Beaver TM, Martin TD. The Florida sleeve: a new technique for aortic root remodeling with preservation of the aortic valve and sinuses. Ann Thorac Surg 2005; 80: 748-750.

16. Hess PJ Jr, Harman PK, Klodell CT, Beaver TM, Bologna MT, Mikhail P, Tribble CG, Martin TD. Early outcomes using the Florida sleeve repair for correction of aortic insufficiency due to root aneurysms. Ann Thorac Surg 2009; 87: 1161-1168.

17. Thubrikar MJ, Nolan SP, Aouad J, Deck JD. Stress sharing between the sinus and leaflets of canine aortic valve. Ann Thorac Surg 1986; 42: 434-440.

18. Misfeld M, Sievers HH. Heart valve macro- and microstructure. Philos Trans R Soc Lond B Biol Sci 2007; 362: 1421-1436.

19. Konstantinov BA, Prelatov VA, Ivanov VA, Malinovskaya TN. Valve sparing operations in heart disease surgery. Medicine, Moscow 1989.

20. Pang DC, Choo SJ, Luo HH, Shomura YU, Daniel S, Nikolic S, Cheung DT, Oury $J H$, Duran CM. Significant increase of aortic root volume and commissural area occurs prior to aortic valve opening. J Heart Valve Dis 2000; 9: 9-15.

21. Lansac E, Lim HS, Shomura Y, Lim KH, Rice NT, Goetz W, Acar C, Duran CM A four-dimensional study of the aortic root dynamics. Eur J Cardiothoracic Surg 2002; 22: 497-503.
22. Peacock JA. An in vitro study of the onset of turbulence in the sinus of Valsalva. Circ Res 1990; 67: 448-460

23. Jones CJ, Sugawara M. "Wavefronts" in the aorta - implications for the mechanisms of left ventricular ejection and aortic valve closure. Cardiovasc Res 1993; 27: 1902-1905

24. Katayama S, Umetani N, Sugiura S, Hisada T. The sinus of Valsalva relieves abnormal stress on aortic valve leaflets by facilitating smooth closure. J Thorac Cardiovasc Surg 2008; 136: 1528-1535.

25. De Paulis R, De Matteis GM, Nardi P, Scaffa R, Buratta MM, Chiariello L. Opening and closing characteristics of the aortic valve after valve-sparing procedures using a new aortic root conduit. Ann Thorac Surg 2001; 72: 487-494.

26. Grande-Allen KJ, Cochran RP, Reinhall PG, Kunzelman KS. Re-creation of sinuses is important for sparing the aortic valve: a finite element study. J Thorac Cardiovasc Surg 2000; 119: 753-763.

27. Leyh RG, Schmidtke C, Sievers HH, Yacoub MH. Opening and closing characteristics of the aortic valve after different types of valve-preserving surgery. Circulation 1999; 100: 2153-2160.

28. Belov YuV, Charchian ER. Exoprosthetic repair of aortic root aneurysms. Cardiology and Cardiovascular Surgery 2009; 6: 82-84.

29. Hess PJ Jr, Harman PK, Klodell CT, Beaver TM, Bologna MT, Mikhail P, Tribble CG, Martin TD. Early outcomes using the Florida sleeve repair for correction of aortic insufficiency due to root aneurysms. Ann Thorac Surg 2009; 87: 1161-1168.

30. Hetzer R, Komoda T, Komoda S, Berger F, Huebler M. New aortic root remodeling surgery in aortic root aneurysm. Ann Thorac Surg 2010; 89: 1260-1264. 